\title{
Model Penyebaran Penyakit SIR Tipe Rantai Binomial dengan Kontak Random dan Waktu Penyembuhan Bernilai Tak Hingga
}

\author{
Ilham Asyifa Maulana Rosyid ${ }^{1}$, Respatiwulan ${ }^{2}$, dan Sri Sulistijowati Handajani ${ }^{3}$ \\ 1,2,3 Program Studi Statistika, Universitas Sebelas Maret \\ 1ilham1234@student.uns.ac.id, ${ }^{2}$ respatiwulan@staff.uns.ac.id, ${ }^{3}$ rr_ssh@staff.uns.ac.id
}

\begin{abstract}
Susceptible-Infected-Recovered (SIR) epidemic model is an epidemic model that illustrates the pattern of disease spread with the characteristics of individuals who have recovered cannot be re-infected and have a permanent immune system. The binomial chain type epidemic model assumes that infection spreads in discrete time units and the number of the infected individuals follows a binomial distribution. This research aims to discuss binomial chain type SIR epidemic model by simulating the model. The transition probability depends on $Y(t)$ the number of infected individuals in the period $t, N_{i}(t)$ the number of individuals encountered, and $p$ the transmission probability. This model also assumes an infinite recovery time $(\Re$ $=\infty$ ). This situation illustrates that infected individuals remain contagious during the period of spread of the disease. This situation can arise when the causative agent of the disease has a long life. Then simulations are performed by giving different transmission probability $p$. The results show that the greater transmission probability will cause the probability of a new individual being infected in the next period to be greater.
\end{abstract}

Keywords : SIR epidemic model, binomial chain, infinite recovery time

\section{Pendahuluan}

Penyebaran penyakit merupakan fenomena alam yang menjadi salah satu permasalahan bagi manusia. Penyebaran penyakit, utamanya penyakit menular yang tidak dapat dikendalikan dalam waktu yang cukup lama dapat menyebabkan epidemi. Perkembangan ilmu pengetahuan di bidang matematika turut memberikan andil dalam penanganan masalah penyebaran penyakit. Salah satu dari peranan matematika adalah dalam menggambarkan fenomena penyebaran penyakit, dimana peranan tersebut dituangkan dalam bentuk model matematika.

Model penyebaran penyakit SIR membagi populasi menjadi tiga kelompok yaitu rentan atau susceptible (S), terinfeksi atau infected (I) dan sembuh atau recovered (R). Kelompok $\mathrm{S}$ adalah kelompok individu yang rentan dan dapat terinfeksi apabila terjadi kontak yang cukup dengan individu terinfeksi. Kelompok terinfeksi I merupakan kelompok individu terinfeksi dan dapat menularkan penyakit pada individu lain. Kelompok sembuh $\mathrm{R}$ merupakan kelompok individu yang sudah sembuh dan tidak dapat terinfeksi kembali. Model matematika penyebaran penyakit SIR ini dapat dipandang sebagai model stokastik 
[1]. Jumlah individu di setiap kelompok pada waktu $t$ merupakan variabel random yakni $S(t), I(t), R(t)$ menyatakan jumlah individu rentan, terinfeksi dan sembuh pada waktu $t$.

Model penyebaran penyakit stokastik antara lain model Greenwood dan model Reed-Frost. Keduanya merupakan model penyebaran penyakit SIR Stokastik tipe rantai binomial. Model tersebut disebut tipe rantai binomial karena model dikembangkan dari percobaan binomial sederhana dengan mengasumsikan bahwa infeksi menyebar dari individu ke individu pada populasi dalam satuan waktu diskrit, membentuk rantai penularan yang ditentukan oleh distribusi binomial [2].

Artikel ini membahas model penyebaran penyakit SIR tipe rantai binomial dengan asumsi modifikasi berupa adanya kontak antara individu $S$ dengan "kelompok bertemu" yaitu kelompok individu yang saling bertemu dalam populasi tersebut serta waktu penyembuhan tak hingga. Jumlah dan komposisi dari "kelompok bertemu" untuk setiap individu rentan adalah random, sehingga asumsi tersebut dapat dituliskan sebagai kontak random. Waktu penyembuhan tak hingga menggambarkan situasi ketika agen penyebab penyakit memiliki umur yang panjang seperti virus HIV pada manusia yang sangat sulit sembuh. Kemudian dilakukan simulasi terhadap model dengan memberikan peluang penularan yang berbeda, simulasi dilakukan untuk melihat variabilitas peluang terdapat satu individu terinfeksi baru pada waktu berikutnya dan durasi penyebaran penyakit.

\section{Landasan Teori}

2.1. Model SIR. Salah satu model yang dapat mengambarkan penyebaran penyakit adalah model SIR (Susceptible-Infected-Recovered). Jika diasumsikan suatu penyakit menyebar dalam suatu populasi, maka dalam populasi tersebut terdiri dari tiga kelompok yaitu S (Susceptible) yaitu kelompok individu yang rentan, I (Infected) yaitu kelompok individu yang terinfeksi dan sembuh $\mathrm{R}$ (Recovered) yaitu kelompok individu yang telah sembuh dari infeksi dan tidak dapat terinfeksi kembali [3]. Asumsi dari model SIR sebagai berikut:

(1) Populasi tertutup dan jumlahnya konstan yaitu $n$.

(2) Populasi homogen sehingga tiap-tiap individu memiliki karakteristik yang sama.

(3) Tidak memperhatikan laju kelahiran dan kematian.

(4) Hanya terdapat satu penyakit yang menyebar dalam populasi.

Untuk selanjutnya penulisan kelompok rentan, terinfeksi dan sembuh pada waktu $t$ menjadi $X(t), Y(t)$ dan $Z(t)$ mengacu pada Tuckwell dan William [4]. 
2.2. Model SIR Tipe Rantai Binomial. Model stokastik penyebaran penyakit tipe rantai binomial merupakan model yang dikembangkan untuk membantu memahami penyebaran penyakit dalam populasi kecil. Terdapat dua model penyebaran penyakit tipe rantai binomial, yaitu model Greenwood dan model Reed-Frost. Model SIR rantai binomial mengasumsikan jumlah individu terinfeksi pada waktu $t+1$ merupakan variabel random berdistribusi binomial dengan parameter $X(t)$ yaitu jumlah individu rentan pada waktu $t$ dan $p(Y(t))$ peluang terinfeksi dari sejumlah individu terinfeksi $Y(t)$. Reed-Frost mengasumsikan bahwa peluang penularan bergantung pada jumlah individu terinfeksi. Sehingga peluang tidak terjadi penularan ketika terdapat sejumlah $y$ individu terinfeksi diberikan di persamaan (1),

$$
1-p(y)=(1-p)^{y}
$$

dengan $p=p(1)$ adalah peluang seorang individu rentan mendapatkan kontak dari seorang individu terinfeksi [4]. Jumlah kontak antara setiap individu terinfeksi dengan individu rentan bergantung pada peluang penularan dan ukuran kelompok bertemu sehingga jumlah individu terinfeksi pada waktu $t+1$ dituliskan pada persamaan (2)

$$
Y(t+1)=X(t)\left(1-(1-p)^{y}\right)
$$

dengan $Y(t+1)$ adalah jumlah individu terinfeksi pada waktu $t+1$ dan $X(t), Y(t)$ secara berurutan merupakan jumlah individu rentan serta terinfeksi pada waktu $t$.

2.3. Distribusi Binomial. Distribusi binomial merupakan barisan dari percobaan Bernouli yang saling independen yang diulang $n$ kali dengan tiap-tiap percobaan hanya menghasilkan dua peristiwa yaitu peristiwa sukses dalam hal ini tidak terjadi penularan dan gagal berarti terjasi penularan. Peluang terjadinya peristiwa sukses dinyatakan dengan $p$ [5]. Suatu variabel random $Y$ dikatakan berdistribusi binomial jika fungsi peluangnya diberikan pada persamaan (3),

$$
P(Y=y)=\left(\begin{array}{l}
n \\
y
\end{array}\right) p^{y}(1-p)^{n-y}
$$

harga harapan dari variabel random $Y$ yang berdistribusi binomial dapat dinyatakan dengan

$$
E(Y)=n p
$$

\section{Metodologi Penelitian}

Penurunan model dilakukan dengan terlebih dahulu menentukan asumsi penyebaran penyakit yaitu asumsi umum ditambahkan dengan asumsi adanya kelompok bertemu dan mengasumsikan waktu penyembuhan yang panjang, sehingga dimungkinkan hampir tidak ada individu sembuh selama waktu penyebaran penyakit. Kelompok bertemu merupakan kelompok individu yang ditemui oleh individu rentan ke- $i$ dengan jumlah dan 
komposisi random dari populasi. Kemudian menentukan persamaan peluang transisinya yaitu peluang adanya individu rentan menjadi individu terinfeksi pada waktu selanjutnya. Pada model ini jumlah individu terinfeksi dipandang sebagai variabel random berdistribusi binomial. Peluang bahwa setiap individu rentan tidak terinfeksi ketika terdapat sejumlah $y$ individu terinfeksi adalah $(1-p)^{y}$. Model yang dibangun merupakan peluang transisi satu individu rentan menjadi terinfeksi.

\section{Hasil dan Pembahasan}

Penurunan model ini mengacu pada penelitian Tuckwell and Williams [4]. Peluang tidak terjadi penularan $p$ sedangkan peluang terjadi penularan individu kelompok penularan menjadi kelompok terinfeksi adalah $(1-p)$ dengan asumsi :

(1) Total populasi adalah konstan sebesar $n$.

(2) Waktu penyebaran adalah waktu diskrit, dengan $t=0,1,2, \ldots$ dan diasumsikan untuk satu satuan waktu adalah satu hari.

(3) Banyaknya individu terinfeksi merupakan variabel random berdistribusi binomial dan $Y^{i}=\left\{Y^{i}(t), t=0,1,2, \ldots,\right\}$, merupakan proses random dengan $i$ menunjukan individu ke- $i$ sedemikian sehingga $Y^{i}(t)=1$ jika individu tersebut terinfeksi pada waktu $t$, sebaliknya $Y^{i}(t)=0$ apabila individu ke- $i$ tidak terinfeksi. Jumlah total individu terinfeksi pada waktu waktu $t$ adalah

$$
Y(t)=\sum_{i=0}^{n} Y^{i}(t), t \geq 0 .
$$

(4) Kelompok bertemu $N_{i}(t)$ merupakan jumlah individu yang melakukan kontak terhadap individu rentan $i$ pada waktu $t$, terdiri dari kelompok yang jumlahnya konstan $n_{i}$ ditambah dengan sejumlah random individu $M_{i}(t)$ pada interval waktu $(t, t+1]$, sehingga $N_{i}(t)=n_{i}+M_{i}(t)$. Komposisi dari kelompok individu $n_{i}$ dan $M_{i}(t)$ sulit ditentukan sehingga diasumsikan keduanya diambil secara random dari populasi, sehingga individu $i$ bertemu dan melakukan kontak dengan sejumlah random $N_{i}(t)$, dengan komposisinya terdiri dari individu terinfeksi atau rentan.

(5) Individu terinfeksi akan tetap menjadi terinfeksi selama $\mathfrak{R}$ waktu berurutan terhitung dari waktu individu pertama kali tertular, jadi apabila individu tertular untuk pertama kali pada waktu $t$ maka individu akan tetap dalam keadaan terinfeksi selama waktu waktu $\{t, t+1, t+2, \ldots, t+\mathfrak{R}-1\}$ dan setelahnya individu akan pulih serta tidak dapat tertular kembali. Pada penelitian ini dipertimbangkan waktu penyembuhan yang tak berhingga $\mathfrak{R}=\infty$. Keadaan ini menggambarkan bahwa individu yang terinfeksi 
tetap menular selama waktu penyebaran penyakit. Situasi seperti itu dapat muncul ketika agen penyebab penyakit memiliki umur yang panjang seperti HIV pada manusia.

(6) Peluang terpilihnya individu terinfeksi secara random pada waktu $t$ adalah $\frac{y(t)}{n}$.

Berdasarkan asumsi nomor 3, proses $Y^{i}=\left\{Y^{i}(t), t=0,1,2, \ldots,\right\}$ dengan $i=$ $1,2, \ldots, n$, sedemikian sehingga $Y^{i}(t)=1$ individu $i$ terinfeksi atau $Y^{i}(t)=0$ apabila individu $i$ tidak terinfeksi. Kemudian proses $X^{i}(t)$ yang menunjukkan individu ke- $i$ rentan atau tidak dan proses $Z^{i}(t)$ yang menunjukkan individu $i$ sebelumnya terinfeksi telah sembuh dan tidak mampu menginfeksi orang lain. Setiap individu dalam kelompok populasi saling asing artinya jika individu $i$ berada pada kelompok $\mathrm{S}$ maka dia tidak berada dalam kelompok I maupun $\mathrm{R}$ sehingga untuk semua individu $i$ pada waktu $t$ dapat di definisikan

$$
X^{i}(t)+Y^{i}(t)+Z^{i}(t)=1 .
$$

4.1 Model dengan Waktu Penyembuhan $\mathfrak{R}$. Penyakit dapat menyebar dari satu individu ke individu yang lain melalui kontak. Misalkan pada waktu $t$, jumlah individu pada kelompok rentan $X(t)$ yang bertemu dan melakukan kontak dengan sejumlah individu pada kelompok terinfeksi $Y(t)$ kemudian tertular, pada waktu $t+1$ jumlah individu terinfeksi adalah $Y(t+1)$. Sedangkan individu yang tidak tertular akan tetap dalam kelompok rentan yaitu $X(t+1)$.

Pada waktu $t+1$ banyak kemungkinan jumlah individu rentan $X(t)$ yang akan menjadi $X(t+1)$ adalah sebesar $\left(\begin{array}{c}X(t) \\ X(t+1)\end{array}\right)$. Jika peluang terjadi penularan antar individu rentan dengan individu terinfeksi adalah $(1-p)$ maka peluang bersama tidak terjadi penularan antara kelompok rentan dan terinfeksi adalah $(1-p)^{Y(t)}$. Oleh karena itu peluang bersyarat terdapat sejumlah individu terinfeksi baru pada waktu berikutnya $Y(t+$ 1) dapat dituliskan di persamaan (4),

$$
P(Y(t+1) \mid X(t), Y(t))=\left(\begin{array}{c}
X(t) \\
X(t+1)
\end{array}\right)\left((1-p)^{Y(t)}\right)^{X(t+1)}\left((1-(1-p))^{Y(t)}\right)^{Y(t+1)}
$$

Menurut Fine [6], harga harapan jumlah rentan pada waktu $t+1$ diberikan pada persamaan (5)

$$
X(t+1)=X(t)(1-p)^{Y(t)}
$$

Harga harapan jumlah individu terinfeksi pada waktu $t+1$ dari variabel random berdistribusi binomial dengan parameter $X(t)$ dan $p(Y(t))$, dapat ditulis pada persamaan (6) 


$$
Y(t+1)=X(t)\left(1-(1-p)^{Y(t)}\right) .
$$

Berdasarkan asumsi nomor 5, misalkan $Y_{m}(t)$ adalah individu terinfeksi pada waktu $t, Y_{m}(t)$ akan tetap dalam keadaan terinfeksi selama $m$ waktu, dengan $m=$ $0,1,2, \ldots, \Re-1$, maka jumlah total individu terinfeksi pada waktu $t+1$ adalah

$$
Y(t+1)=\sum_{m=0}^{\Re-1} Y_{m}(t+1)
$$

dan jumlah total individu recovered pada waktu $t+1$ adalah sebesar

$$
Z(t+1)=Z(t)+Y_{\mathfrak{R}-1}(t)
$$

Berdasarkan persamaan (6), (7) dan (8) diperoleh model penyebaran penyakit SIR tipe rantai binomial sebagai berikut

$$
\begin{aligned}
& X(t+1)=X(t)(1-p)^{Y(t)} \\
& Y(t+1)=\sum_{m=0}^{\Re-1} Y_{m}(t+1) \\
& Z(t+1)=Z(t)+Y_{\Re-1}(t)
\end{aligned}
$$

4.2 Model Waktu Penyembuhan Bernilai Tak Hingga $(\mathfrak{R}=\infty)$. Berdasarkan model yang telah terbentuk pada persamaan (9), bagian ini menjelaskan peluang individu rentan pada waktu $t$ menjadi individu terinfeksi untuk pertama kali pada waktu $t+1$. Peluang ini bergantung pada total jumlah individu terinfeksi $Y(t)=y$ dan sejumlah inidividu yang ditemui oleh tiap-tiap individu $i$ atau dapat disebut sebagai kelompok bertemu $N_{i}(t)$ serta peluang penularan $p$.

Pada asumsi kelompok bertemu, individu $i$ dimungkinkan bertemu dengan sejumlah $n_{i}$ individu secara tetap setiap harinya, misalnya keluarga. Individu $i$ juga bertemu dan melakukan kontak dengan sejumlah random $M_{i}(t)$ individu yang lain, misalnya rekan kerja selama $(t, t+1]$. Total jumlah individu yang bertemu dan melakukan kontak dengan individu $i$ selama $(t, t+1]$ adalah $N_{i}(t)=n_{i}+M_{i}(t)$. Namun akan sulit untuk menentukan komposisi dari kelompok individu $n_{i}$ dan $M_{i}(t)$ sehingga diasumsikan keduanya diambil secara random dari populasi, sehingga individu $i$ bertemu dan melakukan kontak dengan sejumlah random $N_{i}(t)$ individu dalam populasi yang diambil secara independen dan terdistribusi identik untuk setiap $i$ dari sisa populasi.

Peluang penularan ketika individu $i$ bertemu dengan kelompok bertemu $N_{i}(t)$ dipengaruhi oleh adanya individu terinfeksi didalamnya. Distribusi binomial dapat 
digunakan untuk menentukan peluang individu $i$ bertemu tepat dengan $j$ individu terinfeksi dalam $N_{i}(t)$, dengan peluang tersebut dapat dituliskan pada persamaan (10)

$$
P_{j}^{i}\left(y, N_{i}(t) ; n\right) \approx\left(\begin{array}{c}
N_{i}(t) \\
j
\end{array}\right)\left(\frac{y}{n-1}\right)^{j}\left(1-\frac{y}{n-1}\right)^{N_{i}(t)-\mathrm{j}}
$$

dan peluang penularan ketika individu melakukan kontak dengan $j$ individu terinfeksi adalah

$$
p_{j}=(1-p)^{j}
$$

Kemudian peluang individu susceptible $i$ pada waktu $t$ akan menjadi individu terinfeksi pada waktu $t+1$ dapat dihitung dengan persamaan (10) dan (11)

$$
P\left(Y^{i}(t+1)=1 \mid N_{i}(t) X^{i}(t)=1, Y(t)=y, \ldots\right)=\sum_{j}^{N_{i}(t)} p_{j} P_{j}^{i}\left(y, N_{i}(t) ; n\right)
$$

persamaan (12) dapat disederhanakan menjadi

$$
P\left(Y^{i}(t+1)=1 \mid N_{i}(t), X^{i}(t)=1, Y(t)=y, \ldots\right)=1-\left(1-\frac{p y}{n-1}\right)^{N_{i}(t)}
$$

dengan $N_{i}(t)$ trial Benoulli yang berdistribusi identik, dengan peluang bahwa individu tidak terinfeksi pada waktu selanjutnya adalah $\left(1-\frac{p y}{n-1}\right)^{N_{i}(t)}$.

Model tanpa waktu pemulihan menggambarkan bahwa individu terinfeksi tetap dalam keadaan terinfeksi selama waktu penyebaran penyakit. Diasumsikan bahwa pada waktu $t$ terdapat $Y(t)=y$ individu terinfeksi, dan tidak ada individu sembuh, danberarti terdapat $n-y$ individu rentan. Diasumsikan pula bahwa jumlah orang yang bertemu dengan individu ke $i$ atau kelompok bertemu $(N i(t))$ adalah random. Apabila $N i(t)$ independen dan berdistribusi identik, maka peluang tidak ada infeksi baru pada $t+1$ merupakan peluang bersama yang dapat dinyatakan dengan

$$
\begin{aligned}
& P\left(Y(t+1)=y \mid N_{i}(t), i=1, \ldots, n-y ; Y(t)=y\right) \\
& \quad=P\left(Y^{1}(t+1)=0 \mid N_{1}(t), X^{1}(t)=1\right) . P\left(Y^{2}(t+1)=0 \mid N_{2}(t), X^{2}(t)=1\right) \ldots \\
& P\left(Y^{n-y}(t+1)=0 \mid N_{n-y}(t), X^{n-y}(t)=1\right)
\end{aligned}
$$

atau dapat ditulis dengan

$$
P\left(Y(t+1)=y \mid N_{i}(t), i=1, \ldots, n-y ; Y(t)=y\right)=\prod_{i=1}^{n-y}\left(1-\frac{p y}{n-1}\right)^{N_{i}(t)}
$$


dan peluang adanya satu individu terinfeksi baru dapat dituliskan dengan peluang marjinal bahwa satu diantara individu rentan $i$ menjadi terinfeksi pada waktu $t+1$, dimana $i=$ $1,2,3, \ldots, n-y$. Peluang tersebut dapat dituliskan sebagai berikut

$$
\begin{aligned}
P(Y(t+1)=y & \left.+1 \mid N_{i}(t), i=1, \ldots, n-y ; Y(t)=y\right) \\
& =\sum_{i=1}^{n-y}\left[1-\left(1-\frac{p y}{n-1}\right)^{N_{i}(t)}\right] \prod_{j=1}^{n-y}\left(1-\frac{p y}{n-1}\right)^{N_{i}(t)}
\end{aligned}
$$

untuk kemungkinan adanya lebih dari satu individu infected baru akan lebih sulit diformulasikan apabila untuk setiap individu $i$ mempunyai asumsi jumlah kelompok bertemu yang random.

4.3 Simulasi Model. Simulasi model diberikan untuk memperjelas pola penyebaran penyakit SIR dengan $n$ rantai binomial. Pada simulasi ini akan diberikan ukuran populasi sebesar $n=50$ dan 100 dan dengan variasi peluang penularan tiap kontak individu $(p)$ sebesar $p=0,00625 ; 0,0125 ; 0,025 ; 0,05$ dan 0,1. Kelompok bertemu jumlahnya sebesar 1 sampai 5 individu artinya untuk setiap individu $i$ akan melakukan kontak minimal dengan $N_{i}(t)=1$ dan maksimal dengan $N_{i}(t)=5$. Jumlah Kelompok bertemu untuk individu $i$ diperoleh dengan membangkitkan sampel dari distribusi seragam diskrit dengan interval 1 sampai 5. Simulasi dilakukan dengan memberikan nilai awal banyaknya individu terinfeksi sebanyak satu individu $Y(0)=1$. Kemudian akan ditentukan peluang adanya individu terinfeksi baru berdasarkan persamaan (13), untuk $n=50$ peluang adanya individu infected baru dapat dihitung dengan

$$
\begin{gathered}
P\left(Y(t+1)=2 \mid N_{i}(t), i=1, \ldots, 49 ; Y(t)=1\right)= \\
\sum_{i=1}^{49}\left[1-\left(1-\frac{p(1)}{49}\right)^{N_{i}(t)}\right] \prod_{j=1}^{49}\left(1-\frac{p(1)}{49}\right)^{N_{i}(t)}
\end{gathered}
$$

sehingga diperoleh hasil sebagaimana tertulis pada Tabel 1 .

Tabel 1. Peluang Adanya Individu Infected Baru dengan Populasi $n=50$

\begin{tabular}{rc}
\hline \multicolumn{1}{c}{$p$} & $P(Y(t+1)=y+1)$ \\
\hline 0,00625 & 0,000188877 \\
0,0125 & 0,000498146 \\
0,025 & 0,001216707 \\
0,05 & 0,001847982 \\
0,1 & 0,003380969
\end{tabular}


Tabel 1 dan Gambar 1 menunjukkan bahwa, variasi peluang penularan tiap kontak menyebabkan variasi terhadap peluang adanya individu terinfeksi baru pada waktu selanjutnya. Selanjutnya dengan cara yang sama, untuk total populasi $n=100$ diperoleh hasil pada Tabel 2.

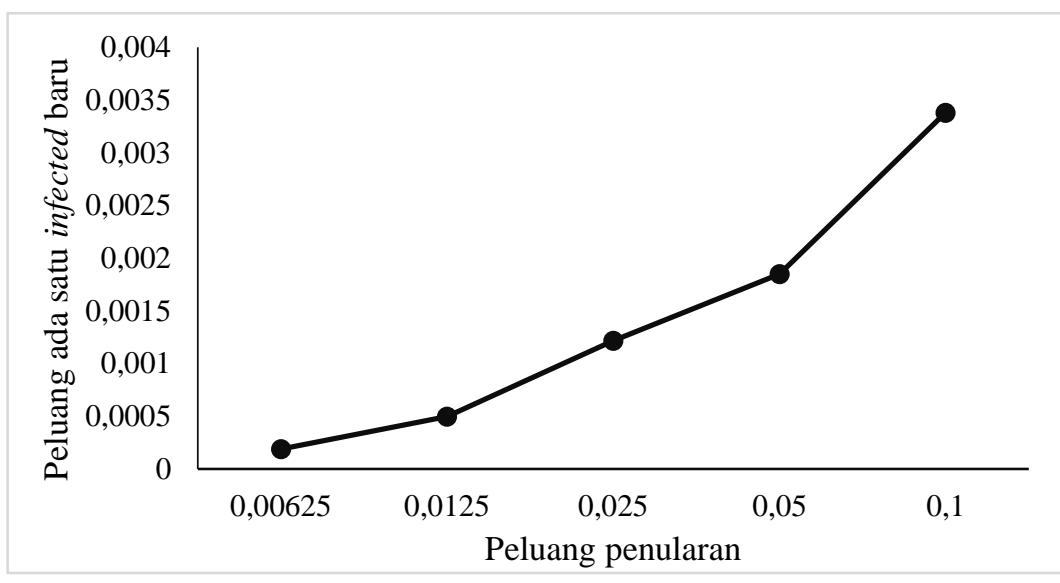

Gambar 1. Peluang Penularan Tiap Kontak Versus Peluang Ada Satu Infected Baru untuk $n=50$

Tabel 2. Peluang Adanya Individu Infected Baru dengan Populasi $n=100$

\begin{tabular}{rc}
\hline \multicolumn{1}{c}{$p$} & $P(Y(t+1)=y+1)$ \\
\hline 0,00625 & $9,353537 \mathrm{e}-05$ \\
0,0125 & 0,000307668 \\
0,025 & 0,000360677 \\
0,05 & 0,000917783 \\
0,1 & 0,001248617 \\
\hline
\end{tabular}

Gambar 2 menunjukkan hasil yang sama pada simulasi dengan total populasi $n=$ 100. Apabila diberikan nilai peluang penularan yang berbeda maka akan diperoleh peluang adanya individu infected baru yang berbeda. Semakin tinggi peluang penularan tiap kontak maka peluang adanya satu individu infected baru pada waktu berikutnya semakin besar. 


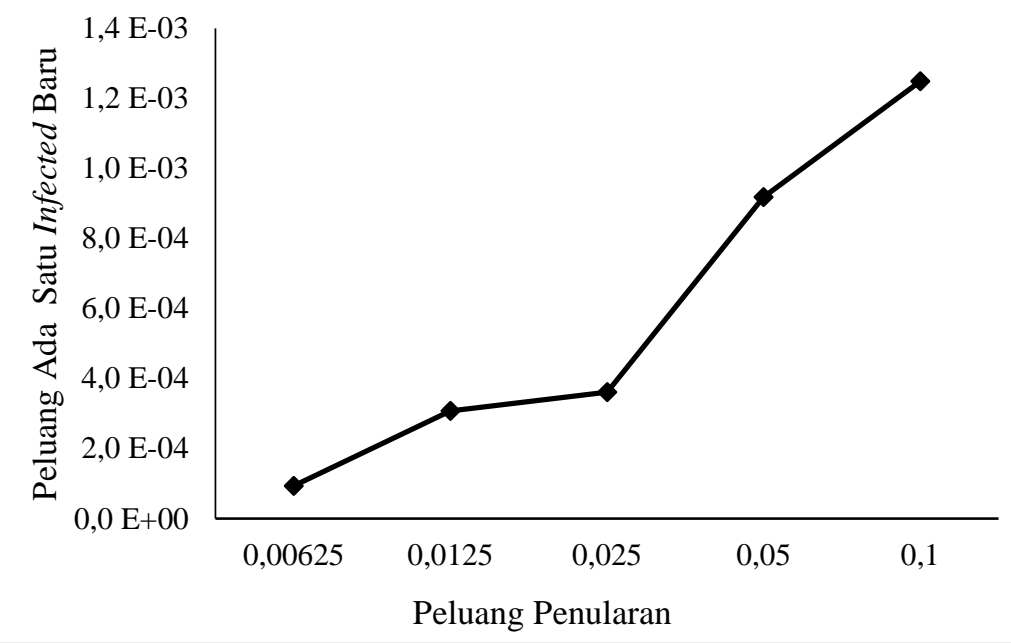

Gambar 2. Peluang Penularan Tiap Kontak vs Peluang Ada Satu Terinfeksi Baru

$$
\text { untuk } n=100
$$

\section{Kesimpulan}

Berdasarkan hasil dan pembahasan yang telah dipaparkan diperoleh kesimpulan bahwa, model epidemi SIR tipe rantai binomial dengan asumsi kontak random dan waktu penyembuhan yang lama bergantung pada peluang individu rentan pada waktu $t$ menjadi individu terinfeksi untuk pada waktu $t+1$. Peluang ini bergantung pada jumlah individu terinfeksi pada waktu $t$ atau $Y(t)$, banyaknya individu yang bertemu dan melakukan kontak dengan individu terinfeksi ke- $i$ atau $N_{i}(t)$ serta peluang penularan tiap kontak $(p)$. Peluang tidak ada infeksi baru pada $t+1$ dituliskan pada persamaan (13) dan peluang adanya satu individu terinfeksi baru pada $t+1$ pada persamaan (14).

Berdasarkan simulasi yang telah dilakukan dengan jumlah total populasi dan peluang penularan diberikan diperoleh semakin tinggi peluang penularan tiap kontak maka peluang adanya satu individu terinfeksi baru pada waktu berikutnya semakin besar.

\section{Daftar Pustaka}

[1] Allen, L. J. S. An Introduction to Stochastic Epidemic Models. Lecture Notes in Mathematics, 81-130. 2008.

[2] Halloran, M. E., Longini, I. M. and Struchiner, C. J. Binomial and Stochastic Transmission Models. Design and Analysis of Vaccine Studies. Statistics for Biology and Health. Springer, New York. 2010.

[3] Hethcote, H. W. The Mathematics of Infectious Diseases. SIAM Rev. Vol. 42, No. 4, 599-653. 2000. 
[4] Tuckwell, H. C., and Williams, R. J. Some Properties of a Simple Stochastic Epidemic Model of SIR Type. Mathematical Biosciences, Vol. 208, No. 1, 76-97. 2007.

[5] Herrhyanto, N. dan Gantini. Pengantar Statistika Matematis. Yrama Widya, Bandung. 2009.

[6] Fine, P. E. M. A Comentary on the Reed-Frost Epidemic Model. American Journal of Epidemiology. No.106, 87-100. 1997. 